\title{
The Price Is Not Always Right: On the Impacts of Commodity Prices on Households (and Countries)
}

Daniel Lederman ${ }^{1}$ and Guido Porto ${ }^{2}$

This paper provides an overview of the impact that one-time changes in commodity and other prices have on household welfare. It begins with a collection of stylized facts related to commodities based on household survey data from Latin America and Africa. The data uncovers strong commodity dependence on both regions: households typically allocate a large fraction of their budget to commodities, and they often also depend on commodities to earn their income. This income and expenditure dependency suggests sizable impacts and adjustments following commodity price shocks. The article explores these effects with a review of the relevant literature. The authors study consumption and income responses, labor market responses, and spillovers across sectors. The paper provides evidence on the relative magnitudes of various mechanisms through which commodity prices affect household (and national) welfare in developing economies. Commodity price changes, Poverty and welfare impacts, Net consumers and net producers. JEL codes: I30, O13, Q17

Energy prices rose more than $140 \%$ between 2000 and 2013, according to the World Bank's energy-price index, while the food-price index rose by more than $80 \%{ }^{3}$ These increases in commodity prices motivated researchers to assess the implications for households and workers in developing countries, as well as policy responses. An example of such research is the World Bank's $\$ 4$ billion contribution to a joint fund with J.P. Morgan, launched on June 21, 2011, to help developing countries invest in commodity-price hedging instruments. ${ }^{4}$ Yet commodity prices have stalled since 2012, and observers are once again concerned about the social and economic consequences of declining commodity prices. ${ }^{5}$ Part of the concern is about the volatility of commodity prices, as much as the medium-term trends, per se. 
Whether it is the trends or the volatility of commodity prices, knowledge about the effects of commodity-price fluctuations on household welfare is useful for policy as much as it is useful for understanding economic behavior. It is also important to have a sense of the magnitudes of the impacts involved.

The objective of this article is to put forth an economic framework for understanding how people in developing countries are affected by relatively permanent changes in commodity and other prices. The approach is to review the literature framed by a model that highlights issues relevant in the discussion of prices and welfare. The literature review canvasses research from various branches, including shocks to exchange rates, financial crises, and trade reforms. In all these cases, the shocks manifest themselves as price changes, and thus the findings are relevant for the discussion of commodity prices. We complement the literature review with a detailed analysis of household-survey data on commodity dependence in Latin America and Africa.

Since we are interested in the impact of commodity prices on household welfare and behavior, our framework builds on agricultural household models. This framework analyzes how households choose consumption bundles and how they earn their living. In some cases, especially in rural areas, income is generated by agricultural production (profits). In other cases, where the economy is more industrialized, wages and employment are the predominant sources of income, which can be affected by commodity prices. Since prices can affect both consumption and income, the simple framework opens the door to a discussion of how household welfare is affected by changes in commodity prices, both in the short- and long-run. The literature provides numerous empirical findings that can bring together various pieces of the puzzle illustrated by the framework.

The paper is structured as follows. First, we review the literature on the firstorder impacts of price changes. These are the impacts that would take place if households adjust neither the quantities of commodities that they consume nor change the sources of income they receive in response to the price change. The article derives the commonplace net-consumer-versus-net-producer result, which establishes that a price increase hurts net-consumers and benefits net-producers.

Second, we discuss spillovers from commodity prices to other sectors. This refers to, for instance, whether households adjust all consumption choices in response to higher food prices, or whether only food expenditures are affected. We include a discussion of scenarios where commodities are used as inputs into the production of other goods. Consequently, changes in commodity prices (such as oil) may affect the cost, and thus the price, of certain goods (such as transport). Finally, we also report evidence on spillovers in employment and wages; changes in food prices can affect wages and employment not only in the food sectors (primary, agro-manufacturers) but also in non-food sectors.

Third, the article reviews how prices are transmitted to the local economy. Because commodities are traded in international markets, most of the shocks 
associated with commodity prices are global. Consequently, a relevant question is to what extent do changes in international prices pass through to domestic markets?

Fourth, the article explores available evidence on consumption and production responses. Here, we review how consumers adjust the quantity and quality of the consumption basket, as well as other behavioral responses associated with consumption. We also explore some of the patterns of adjustment in production, particularly supply responses in agriculture.

It is important to mention at the outset that there are at least five related literature surveys. These include Winters, McCulloch, and McKay (2004) and Goldberg and Pavcnik (2004), both of which cover trade liberalization and poverty; Goldberg and Pavcnik (2007) and Harrison, McLaren, and McMillan (2011), which cover trade and the distribution of income; and Lederman (2013), which covers trade and inclusive growth. Our review complements this work by merging issues of poverty with issues of inequality. Furthermore, we have a somewhat narrower focus, as we are mainly interested in commodity prices, but we take a somewhat deeper look at some of these issues, all in the context of a general framework.

The rest of this paper is organized as follows. The following section presents an overview of household commodity dependence in Latin America and Africa. Using various household income and expenditure surveys from Latin American and African countries, we estimate the average budget shares spent on commodityrelated sectors (mostly food and energy), and the average income share derived from commodity-related sectors (agriculture, forestry, fishing, mining, food manufactures, and energy). The data reveal strong commodity dependence on both regions. The next section introduces the analytical framework and reviews the literature that measures those effects using data from developing countries. The implications of price changes for net-consumers and net-producers are central to this analysis, with labor markets, various types of spillovers across markets, and imperfect price transmission of border prices all playing fundamental supporting roles in the story. The subsequent section turns to departures from first-order effects and studies the role of household adjustments in production and consumption. This is followed by a simple example of the magnitudes of the different channels identified in the paper using Mexican data, while the final section concludes.

\section{Commodity Dependence: Stylized Facts}

This section characterizes the dependence on commodities of households in developing countries. To study dependence on consumption, we focus on expenditure shares spent on items related to commodities, mainly food and energy. Households' dependence on commodities on the income side is then measured by income shares in agriculture (including forestry and fishing), mining, food manufactures (beverages, 
food, and tobacco), and energy. An important aspect of the analysis is related to poverty and inequality, because dependence on commodities either on the consumption or the income side can vary across quintiles of the income distribution during a given point in time.

Regarding commodity-dependence on the consumption side, table 1 presents the average expenditure shares on commodities for eight Latin American countries and 19 African countries. ${ }^{6}$ In Latin America, there is significant cross-country variation in the average share spent on commodities, ranging from an average share of 71.3 percent in Bolivia to 31.7 percent in Mexico. A common feature in all these countries is that the share of commodity expenditures decreases across quintiles. This is

Table 1. Commodity Expenditure Shares, Latin America and Africa

\begin{tabular}{|c|c|c|c|c|c|c|}
\hline & \multicolumn{5}{|c|}{ Quintiles $\mathrm{p} / \mathrm{c}$ expenditures } & \multirow{2}{*}{ Total } \\
\hline & (1) & (2) & (3) & (4) & (5) & \\
\hline Argentina & 61.8 & 48.9 & 42.3 & 37.5 & 29.0 & 43.9 \\
\hline Bolivia & 82.9 & 78.7 & 73.0 & 67.6 & 54.4 & 71.3 \\
\hline Colombia & 80.1 & 69.1 & 61.7 & 55.6 & 41.6 & 61.6 \\
\hline El Salvador & 65.2 & 59.6 & 54.6 & 49.4 & 39.0 & 53.5 \\
\hline Mexico & 40.6 & 36.2 & 32.4 & 28.4 & 20.8 & 31.7 \\
\hline Nicaragua & 63.5 & 60.9 & 57.3 & 54.4 & 41.6 & 55.5 \\
\hline Panama & 60.0 & 49.0 & 43.9 & 37.4 & 28.3 & 43.7 \\
\hline Peru & 60.1 & 50.6 & 42.6 & 35.8 & 26.1 & 43.0 \\
\hline Burundi & 56.3 & 60.7 & 63.1 & 61.9 & 53.2 & 59.1 \\
\hline Benin & 65.5 & 63.8 & 62.9 & 59.8 & 56.5 & 61.7 \\
\hline Burkina Faso & 77.1 & 72.5 & 67.4 & 60.9 & 48.0 & 65.2 \\
\hline Côte d'Ivoire & 57.2 & 56.6 & 55.8 & 49.3 & 39.4 & 51.6 \\
\hline Cameroon & 71.7 & 69.7 & 67.1 & 62.3 & 53.3 & 64.8 \\
\hline Ethiopia & 84.0 & 79.7 & 77.0 & 70.5 & 55.5 & 73.3 \\
\hline Ghana & 71.2 & 68.5 & 67.1 & 66.6 & 65.4 & 67.8 \\
\hline Gambia & 67.6 & 71.3 & 71.0 & 70.9 & 68.6 & 69.9 \\
\hline Guinea Bissau & 74.5 & 76.6 & 76.5 & 77.3 & 71.5 & 75.3 \\
\hline Kenya & 85.0 & 82.7 & 80.7 & 76.6 & 67.8 & 78.5 \\
\hline Madagascar & 89.6 & 90.5 & 90.7 & 90.6 & 88.1 & 89.9 \\
\hline Mali & 79.5 & 74.4 & 73.1 & 67.5 & 68.8 & 72.7 \\
\hline Malawi & 81.2 & 79.9 & 78.4 & 74.9 & 69.2 & 76.7 \\
\hline Nigeria & 92.4 & 82.6 & 81.6 & 80.5 & 74.7 & 82.3 \\
\hline Rwanda & 78.8 & 69.1 & 60.8 & 49.7 & 27.7 & 57.2 \\
\hline Senegal & 63.7 & 63.2 & 62.7 & 59.8 & 54.7 & 60.8 \\
\hline Tanzania & 90.0 & 88.4 & 85.8 & 82.9 & 74.9 & 84.4 \\
\hline Uganda & 74.7 & 75.5 & 71.9 & 67.1 & 53.0 & 68.4 \\
\hline South Africa & 63.6 & 55.7 & 46.7 & 32.1 & 15.6 & 42.7 \\
\hline
\end{tabular}

Note: Authors' own elaboration based on household surveys. 
expected due to Engel's Law: richer households typically spend a smaller share of their total expenditures on food. In Bolivia, for example, the average commodity share is 82.9 percent in the first quintile and 54.4 percent at the top quintile. In Mexico, the average share of the bottom quintile is 40.6 percent and it is 20.8 percent at the top. In Colombia, the poorest households spend, on average, 80.1 percent on commodities; the richest households spend 41.6 percent. Differences in the populations covered by the surveys across countries (i.e., urban versus rural populations) can clearly account for part of the differences in the average commodity expenditure shares. Nevertheless, the data reveal a very high commodity dependence on the consumption side, especially for the poorest households. In Africa, there is also significant variation across countries, from a minimum average share of 42.7 percent in South Africa, to 84.4 percent in Tanzania, and a maximum of 89.9 percent in Madagascar. The commodity dependence on consumption seems higher in Africa than in Latin America, however. In most countries, commodity dependence in consumption is more prevalent at the bottom of the quintile distribution. This means that Africa and Latin America are both highly dependent on commodities and, moreover, this dependence declines with household income. This pattern explains the literature's concerns about the poverty impacts of commodity price hikes.

Table 2 turns to dependence on the income side. The aim is to measure the share of household income derived from commodities, including income from employment (wages) and self-employment (for instance, agricultural home production). Starting with Latin American data for 2004, Table 2 reports the total combined share of income derived from commodities, which varies widely across countries. This comparison, however, is unlikely to be very useful because of differences in coverage. An example of this is Argentina, which despite being a country with a relatively important agricultural sector, the household survey suggests that only 3.2 percent of household income is, on average, derived from commodities. This is clearly more a manifestation of the urban focus of the survey than of the economy. In the discussion that follows, it is thus convenient to focus more on within-country comparisons across quintiles. A regularity in most of our Latin American data is that lower quintiles exhibit higher shares of income derived from "commodities." The differences are sometimes important. In Paraguay, for instance, while the bottom quintile earns 44.4 percent of income from commodities, the top quintile earns only 14.7 percent.

We uncover similar patterns in the African data. The income commodity dependence in Africa is very high (higher than in Latin America) and varies across countries. The lower quintiles also tend to show higher commodity dependence. In Ghana, for instance, the share of income derived from commodities is 71.4 in the first quintile, and 27.1 in the top quintile. Table 2 shows that in the data, most of the dependence from commodities in Africa is related to dependence on agriculture. 
Table 2. Commodity Income Shares, Latin America and Africa

\begin{tabular}{|c|c|c|c|c|c|c|}
\hline & \multicolumn{5}{|c|}{ Quintiles p/c income } & \multirow{2}{*}{ Tota } \\
\hline & $(1)$ & (2) & (3) & (4) & (5) & \\
\hline Argentina & 3.1 & 3.1 & 3.2 & 3.2 & 3.5 & 3.2 \\
\hline Bolivia & 38.2 & 19.6 & 17.1 & 13.8 & 10.6 & 19.9 \\
\hline Brazil & 22.3 & 14.8 & 10.1 & 7.8 & 5.5 & 12.1 \\
\hline Chile & 17.7 & 15.6 & 13.4 & 10.8 & 9.0 & 13.3 \\
\hline Colombia & 13.7 & 14.7 & 11.0 & 8.3 & 6.2 & 10.8 \\
\hline Costa Rica & 26.0 & 23.9 & 19.1 & 13.1 & 8.9 & 18.2 \\
\hline Dominican Republic & 22.0 & 16.1 & 12.7 & 12.4 & 7.4 & 14.1 \\
\hline Ecuador & 44.1 & 33.9 & 24.5 & 17.5 & 11.5 & 26.3 \\
\hline El Salvador & 19.6 & 17.1 & 10.9 & 7.8 & 5.4 & 12.2 \\
\hline Guatemala & 25.2 & 23.0 & 20.6 & 14.3 & 11.1 & 18.8 \\
\hline Honduras & 43.7 & 34.8 & 21.8 & 14.1 & 11.1 & 25.1 \\
\hline Mexico & 24.1 & 14.0 & 11.0 & 7.1 & 6.4 & 12.5 \\
\hline Nicaragua & 36.9 & 29.6 & 20.8 & 15.7 & 15.0 & 23.6 \\
\hline Panama & 32.9 & 17.3 & 11.6 & 9.7 & 4.5 & 15.2 \\
\hline Paraguay & 38.4 & 27.9 & 22.5 & 17.1 & 15.5 & 24.3 \\
\hline Peru & 37.6 & 27.1 & 17.3 & 11.2 & 9.5 & 20.5 \\
\hline Uruguay & 9.6 & 6.9 & 4.7 & 3.8 & 3.5 & 5.7 \\
\hline Venezuela & 23.1 & 19.3 & 13.5 & 11.8 & 8.2 & 15.2 \\
\hline Burundi & 54.0 & 57.9 & 60.8 & 59.6 & 51.7 & 56.8 \\
\hline Benin & 60.6 & 58.3 & 56.9 & 54.1 & 52.2 & 56.4 \\
\hline Burkina Faso & 73.9 & 69.4 & 64.3 & 57.3 & 43.7 & 61.7 \\
\hline Côte d'Ivoire & 57.1 & 56.5 & 55.5 & 49.0 & 38.6 & 51.3 \\
\hline Cameroon & 68.4 & 66.8 & 64.3 & 59.9 & 51.7 & 62.2 \\
\hline Ethiopia & 82.4 & 78.0 & 75.2 & 68.3 & 52.6 & 71.3 \\
\hline Ghana & 67.5 & 65.2 & 64.3 & 63.8 & 62.5 & 64.7 \\
\hline Gambia & 67.3 & 70.8 & 70.0 & 69.4 & 66.4 & 68.8 \\
\hline Guinea Bissau & 68.4 & 72.6 & 72.0 & 73.0 & 67.3 & 70.7 \\
\hline Kenya & 83.0 & 80.9 & 78.8 & 74.6 & 65.6 & 76.6 \\
\hline Madagascar & 85.7 & 87.5 & 88.0 & 87.8 & 85.0 & 86.8 \\
\hline Mali & 76.8 & 71.0 & 69.4 & 63.1 & 63.7 & 68.8 \\
\hline Malawi & 58.8 & 61.0 & 60.9 & 59.2 & 55.6 & 59.1 \\
\hline Nigeria & 88.5 & 75.3 & 75.0 & 74.8 & 69.6 & 76.6 \\
\hline Rwanda & 77.7 & 67.3 & 59.1 & 47.9 & 26.4 & 55.7 \\
\hline Senegal & 61.6 & 61.0 & 60.2 & 57.1 & 51.8 & 58.3 \\
\hline Tanzania & 90.0 & 88.4 & 85.8 & 82.9 & 74.9 & 84.4 \\
\hline Uganda & 71.2 & 73.0 & 69.3 & 64.3 & 49.5 & 65.5 \\
\hline South Africa & 58.8 & 51.6 & 43.9 & 31.0 & 15.4 & 40.1 \\
\hline
\end{tabular}

Note: Authors' own elaboration based on household surveys.

Since the data from both regions indicates that poor households are on average highly dependent on commodities on both the consumption and income sides, the distinction between net-consumers and net-producers will become particularly 
relevant for the literature that attempts to assess the distributional and poverty impacts of commodity-price fluctuations.

As a preliminary step in this direction, it is worth analyzing the evolution of consumption and income dependence on commodities during a period of time when global commodity prices rose. The purpose of the empirical exercise is to describe the changes in income shares observed in the data from 2004 to 2008. Transitions in and out of dependency can be studied with panel data, which is unavailable in our sample countries. We can, however, build pseudo-panels of households using repeated cross-sections with the method proposed by Dang, Lanjouw, Luoto, and McKenzie (2011). Since only the income surveys in Latin America are repeated cross-sections, we focus here solely on income commodity dependence for Latin America. Due to sampling and measurement issues, one can obtain a distorted view of over-time trends by looking just at the household expenditures and incomes between cross sections. What is needed is a methodology that removes the effect of changes in household samples on the average household consumption and income shares derived from commodities.

To build the 2004-2008 pseudo-panel, we focus on households observed in 2004 and estimate commodity income shares for these households in 2008. This procedure requires the estimation of a regression model for commodity income shares separately for the 2004 and 2008 samples. We then use the estimates from the 2008 sample, together with the residuals from the 2004 regression to produce counter-factual panels. Intuitively, we predict average income shares using the observed covariates in 2004 and the estimated parameters for $2008 .^{7}$

The results are reported in table 3 . The first row reproduces the observed income shares in 2004 that were reported in table 2, while the second row shows the predicted 2008 shares. A key result is that income dependence on commodities increased in Chile, El Salvador, Honduras, Peru, and Uruguay, which is expected given the rise in global commodity prices. However, dependency remained roughly constant in (urban) Argentina and in the Dominican Republic; Brazil and Mexico experienced a slight decline in commodity income dependence, while in Costa Rica, Ecuador, Panama, and Paraguay, the decline was large. This international heterogeneity might be surprising given the commodity price boom, but differences are expected due to various factors discussed below.

It is also noteworthy that the dynamics of income dependence on commodities varies across quintiles within countries. In El Salvador, Honduras, and Uruguay, income dependence increased not only on average, but also for all quintiles. In Chile average dependence rose, but it decreased for lower quintiles and increased for higher quintiles. In contrast, in Peru, average dependence also rose, but it increased for lower quintiles and decreased for higher quintiles. In Argentina and the Dominican Republic, average dependence remained constant, but increased for low quintiles and declined for high quintiles in Argentina; it declined for low quintiles 
Table 3. Commodity Income Shares Methodology Using Repeated Cross-sections, Latin America, 2004-2008

\begin{tabular}{|c|c|c|c|c|c|c|c|}
\hline & \multirow[b]{2}{*}{ Year } & \multicolumn{5}{|c|}{ Quintiles p/c income } & \multirow[b]{2}{*}{ Total } \\
\hline & & (1) & (2) & (3) & (4) & (5) & \\
\hline \multirow[t]{2}{*}{ Argentina } & 2004 & 3.1 & 3.1 & 3.2 & 3.2 & 3.5 & 3.2 \\
\hline & 2008 & 4.2 & 3.8 & 3.2 & 3.0 & 2.5 & 3.3 \\
\hline \multirow[t]{2}{*}{ Brazil } & 2004 & 22.3 & 14.8 & 10.1 & 7.8 & 5.5 & 12.1 \\
\hline & 2008 & 16.9 & 14.6 & 12.0 & 9.6 & 5.9 & 11.8 \\
\hline \multirow[t]{2}{*}{ Chile } & 2003 & 17.7 & 15.6 & 13.4 & 10.8 & 9.0 & 13.3 \\
\hline & 2009 & 16.0 & 16.0 & 14.0 & 12.6 & 10.9 & 13.9 \\
\hline \multirow[t]{2}{*}{ Costa Rica } & 2004 & 26.0 & 23.9 & 19.1 & 13.1 & 8.9 & 18.2 \\
\hline & 2008 & 18.9 & 20.3 & 17.5 & 13.6 & 8.1 & 15.7 \\
\hline \multirow[t]{2}{*}{ Dominican Republic } & 2004 & 22.0 & 16.1 & 12.7 & 12.4 & 7.4 & 14.1 \\
\hline & 2008 & 17.2 & 13.9 & 11.4 & 9.5 & 6.7 & 11.7 \\
\hline \multirow[t]{2}{*}{ Ecuador } & 2004 & 44.1 & 33.9 & 24.5 & 17.5 & 11.5 & 26.3 \\
\hline & 2008 & 32.3 & 28.6 & 24.4 & 19.8 & 12.3 & 23.5 \\
\hline \multirow[t]{2}{*}{ El Salvador } & 2004 & 19.6 & 17.1 & 10.9 & 7.8 & 5.4 & 12.2 \\
\hline & 2008 & 28.3 & 22.4 & 17.9 & 14.0 & 8.0 & 18.1 \\
\hline \multirow[t]{2}{*}{ Honduras } & 2004 & 43.7 & 34.8 & 21.8 & 14.1 & 11.1 & 25.1 \\
\hline & 2008 & 44.4 & 39.4 & 29.4 & 20.6 & 12.6 & 29.3 \\
\hline \multirow[t]{2}{*}{ Mexico } & 2004 & 24.1 & 14.0 & 11.0 & 7.1 & 6.4 & 12.5 \\
\hline & 2008 & 18.9 & 13.9 & 11.1 & 9.4 & 7.0 & 12.1 \\
\hline \multirow[t]{2}{*}{ Panama } & 2004 & 32.9 & 17.3 & 11.6 & 9.7 & 4.5 & 15.2 \\
\hline & 2009 & 20.7 & 14.6 & 10.9 & 9.4 & 4.2 & 12.0 \\
\hline \multirow[t]{2}{*}{ Paraguay } & 2004 & 38.4 & 27.9 & 22.5 & 17.1 & 15.5 & 24.3 \\
\hline & 2008 & 33.0 & 26.9 & 22.9 & 19.1 & 14.7 & 23.3 \\
\hline \multirow[t]{2}{*}{ Peru } & 2004 & 37.6 & 27.1 & 17.3 & 11.2 & 9.5 & 20.5 \\
\hline & 2008 & 39.1 & 29.4 & 20.7 & 13.1 & 7.7 & 22.0 \\
\hline \multirow[t]{2}{*}{ Uruguay } & 2004 & 9.6 & 6.9 & 4.7 & 3.8 & 3.5 & 5.7 \\
\hline & 2008 & 14.9 & 14.5 & 12.8 & 11.3 & 8.6 & 12.4 \\
\hline
\end{tabular}

and increased for high quintiles in the Dominican Republic. In Brazil, Ecuador, Mexico, and Paraguay, average dependence rose, declined for low quintiles, but increased for higher quintiles. Finally, in Costa Rica and Panama, dependence declined for the average as well as for all quintiles.

These results uncover several observations that are important for the subsequent analysis. First, the data show that households adjust after price shocks. In fact, the commodity income shares changed between 2004 and 2008, when global prices rose to record levels. Second, these adjustments were heterogeneous, not only across countries but also across quintiles of the distribution of income within countries. In what follows, the literature review aims to shed light on the impacts of 
commodity price changes on household welfare and on household responses and adjustments in response to price signals.

\section{Price Changes and Household Welfare}

This section explores the impacts of price changes on household welfare. Our analytical framework builds on standard agricultural household models, as in Singh, Squire, and Strauss (1986). Although this framework has influenced a large body of research spanning various fields of economics, the ongoing discussion will modify it as needed to illustrate key issues associated with the welfare impacts of commodity price changes.

The framework analyzes the consequences of price variations from the viewpoint of households. Analyses of welfare changes resulting from such price signals tend to follow the approach pioneered by Dixit and Normal (1980), in which a household's budget constraint is (at least initially) assumed to be fixed. ${ }^{8}$ Simply put, in equilibrium, household expenditures (including savings) have to be financed with household income (including transfers).

In turn, total household expenditures are, by definition, the sum of expenditures across goods, evaluated at their corresponding prices and quantities (for a given level of household utility). However, the household's decision about how much to spend depends on the prices of the consumed goods, on the level of utility, and on other household characteristics (such as household composition).

A household's income, on the other hand, comprises the sum of the wages of all working members of the household plus profits from business or other economic activities. Profits include, for instance, the net income from agricultural production or farm enterprises; they depend on prices, technical capacity, and household characteristics. Since profits are defined as sales net of purchases of inputs, some of the costs imposed by taxes on inputs or intermediate goods can be assessed by their impacts on profits. Income may also comprise transfers (public or private), savings, and other unmeasured returns to factors of production, such as land holdings.

This simple framework highlights the fact that household welfare depends on market equilibrium variables such as prices and wages (that affect household choices) and also on household endowments. For example, household consumption depends on the prices of consumer goods, and household income depends on the type of labor endowment (skilled, unskilled), the market wage rate, and the prices of goods produced by economic enterprises run by members of the household. It follows that changes in commodity prices affect welfare directly via consumption and production decisions, and that these impacts are heterogeneous insofar as they depend on household choices and endowments. In addition, there are shortrun impacts when households do not adjust their consumption, employment, or 
production choices; medium-run impacts refer to the welfare (or consumption or income) effects that take into account partial adjustments; and long-run impacts take into account income growth, investments, and other factors that are related to long-run choices. In other words, the time horizon associated with the impact of price changes on household welfare is commonly defined by the extent to which a household has been able to optimize its total consumption or income in light of the price changes.

\section{First-order Impacts}

Let us consider now the impacts of changes in the price of a commodity. To simplify, we follow Deaton (1989a) and assume that the principle of "separability" holds. ${ }^{9}$ Under this assumption, production decisions are independent of consumption decisions (utility maximization). This means that we can consider the income level of the household as exogenous (once optimal production decisions have been made) when utility maximization takes place as the household adjusts its consumption bundle. The separability assumption is not just a technicality: it allows us to simplify the welfare analysis, but it is valid only under certain economic conditions, such as perfect and complete markets for goods, credit, insurance, and so on. ${ }^{10}$

Prices affect both expenditures and income, even if they do so separately. On the consumption side, consumers are worse off if prices go up but are better off if prices go down. In a first-order approximation, these impacts can be measured with budget shares. That is, the size of the effect of a price change on a household directly depends on how important the good is in the household's total expenditures. On the income side, there is also a direct impact on profits if the household produces the affected good, which depends on the share of income attributed to this good. In rural economies, this source of income can account for a large fraction of total income. In more urbanized economies with more developed labor markets (as in many places in Latin America), the role of the direct production of (agricultural) goods tends to be less important.

Comparisons of budget shares and income shares establish a key result in the literature: a price increase hurts net-consumers (defined by the difference between expenditures and incomes associated with the commodity whose price changed), and benefits net-producers. The opposite is true for price declines: net-consumers are made better off and net-producers worse off. Further, the direction of welfare impacts carries over to the level of a national economy or any aggregate unit of analysis: a country that is a net exporter of an agricultural good will benefit, on average, from price increases, whether they come from global market fluctuations or from international policy reforms such as the international liberalization of agricultural trade policies or subsidies; but net-importers will probably be hurt by those 
changes. In the context of the recent food crisis, for instance, this implies that countries that are net-importers of food were in principle hurt, while net-exporters were the winners.

\section{Households, Net-Consumers, Net-Producers and Inequality}

The net-consumer/net-producer result was introduced by Deaton (1989a), who used data from the Thailand Socioeconomic Survey of 1981-82 to explore the distributional consequences of an export tax on rice across Thai households. He found that an increase in the price of rice (resulting from the elimination of the export tax) would benefit the average household. The average poor, as well as the average rich, would benefit little. The benefits for the poor are small because they tend to both consume and produce lots of rice, thus selling little. The average benefit to the rich is also small because while sellers are often large, there are few of them among the rich. The gains would be much higher in the middle of the income distribution, indicating that the middle class would gain the most from higher rice prices. ${ }^{11}$

The ideas introduced in Deaton's work have been, and still are, extensively utilized in the literature. Early examples include the following authors: Deaton (1989b), who reviews applications for Cote d'Ivoire, Indonesia, and Morocco; Budd (1993), who investigates food prices and rural welfare in Cote d'Ivoire; Benjamin and Deaton (1993), who study cocoa and coffee in Cote d'Ivoire; Barret and Dorosh (1996), who look at rice prices in Madagascar; and Sahn and Sarris (1991), who examine structural adjustments in several Sub-Saharan African countries. Deaton (1997) provides an account of the early use of these techniques in distributional analysis of pricing policies.

Recently, there has been a rebirth of this type of work, motivated by the foodprice "crisis" associated with skyrocketing prices in global markets. Ivanic and Martin (2008) cover ten case studies using household survey data from Bolivia (2005), Cambodia (2003), Vietnam (1998 and 2004), Malawi (2004), Nicaragua (2001), Pakistan (1999), Peru (2003), and Zambia (1998). These authors find an overall poverty-increasing impact of higher food prices because in the sample, most poor households are net-consumers of food (both in urban and rural areas).

Wodon et al. (2008) apply this method to a dozen West and Central African countries, including Burkina Faso (2003), Ghana (2005-2006), Democratic Republic of Congo (2005), Gabon (2005), Guinea (2002-2003), Liberia (2007), Mali (2006), Niger (2005), Nigeria (2003-2004), Senegal (2006), Sierra Leona (2003), and Togo (2006). The authors focus on rice, wheat, maize, other cereals, milk, sugar, and vegetable oils and find that a 50 percent increase in prices for selected food items would cause an average increase in the share of the population in poverty of between 2.5 and 4.4 percentage points. The average impact would be 
between 3.7 and 5.2 percentage points in urban areas, and between 2.2 and 4.1 points in rural areas. These authors also find significant heterogeneity across countries, as expected.

While the net-consumer/net-producer result is intuitive, it rests on two critical assumptions, namely that the first-order approximation is valid and that labor markets are unaffected by the price change (Deaton 1997). The first-order approximation is analytically useful, but it is valid conceptually only for small price changes. We say "conceptually," because in principle budget and income shares could be used to measure the distributional effects of both small and large price changes, but the approximation error will be larger when price changes are large. In these cases, it is crucial to incorporate supply and demand responses, and we discuss these below. The role of labor markets is discussed next.

\section{Labor Markets}

Price changes also affect wages; the mechanisms are simple. Consider, for instance, a small, open economy that takes commodity prices as given in international markets. Changes in relative product prices cause some sectors to expand and some others to contract. As a result, labor demand for different types of labor in different sectors can change, thereby affecting equilibrium wages. ${ }^{12}$ In the literature, these responses are captured by "wage-price" elasticities, which measure the proportional response of wages to price changes. These elasticities may vary across members of a household when they are endowed with different skills (unskilled, semi-skilled or skilled labor), or if they work in different sectors (industry premia). Clearly, if countries differ in technologies, endowments, or labor regulations, the responses of equilibrium wages to prices can be heterogeneous across countries as well.

The response of wages can generate first-order effects on household welfare. To account for these responses, the standard net-consumer/net-producer proposition needs to be modified. To illustrate, consider the extreme case where a farm household consumes a product but does not produce it. Instead, the household earns income from selling labor to neighboring farms. By omitting wages, this household would be mistakenly classified as a net-consumer and could thus be presumably hurt by a price increase. But if wages respond positively to prices, the final welfare effect may not necessarily entail a loss.

This type of wage response was studied in Ravallion (1990), who explored the conditions under which net consumers of food products in Bangladesh lose or gain in the face of increased food prices when rural wages adjust. Ravallion estimates low elasticities of agricultural wages to food prices and concludes that responses are unlikely to be strong enough to offset the short-run adverse distributional effects of higher food prices. The long-run estimates appear to be more favorable to the poor, 
but it would nevertheless take around four years for any gains to materialize. Boyce and Ravallion (1991) take another look at this issue using newer data for Bangladesh. These authors set up a dynamic econometric model of agricultural wages and rice prices and find that increases in rice prices relative to the prices of manufactured goods have adverse effects on the real wages (measured per quantity of rice) in both the short- and long-run.

In a study of informal export barriers and poverty in Moldova, Porto (2005) amends the first-order approximation used by Deaton (1989a) to allow wages to adjust. In this setup, exporters produce agro-manufactured goods (i.e., wines or apple juice) for international markets. These exporters purchase primary products from the farmers (grapes, apples) and manufacture exports using, among other inputs, labor. Farmers are endowed with land and labor and allocate time (net of leisure) to the "farm" labor market, the home (land) plot to produce primary inputs (grapes) for sale, or to work in nearby farms. In this framework, Porto derives additional welfare impacts given by the direct impact on wages. Also, a given farm can either sell or purchase labor in the "farm-labor" market, and consequently, the estimation of the first-order welfare effects needs to include the additional impacts that arise due to changes in wage earnings or paid wages. Porto (2005) finds that increases in the prices of agro-manufactured exports such as wines (a major export sector in Moldova) have sizeable poverty-reducing impacts. Wages respond positively to export prices and this causes first-order gains that dominate both the consumption losses due to higher consumer prices and the profit losses due to higher wages paid to hired labor.

Porto (2006) studies a case where households consume products and sell labor in the market, but do not produce farm products. This author's model applies well to urban, middle-income economies where farm activities are not relevant (and are not captured by the available household surveys, either). Porto explores the distributional consequences of MERCOSUR (a regional trade agreement between Argentina, Brazil, Paraguay, and Uruguay) in Argentina and finds welfare gains for the average poor and middle-income households (and negligible effects for the wealthiest households). This is because on top of gains from price reductions due to tariff cuts, there are changes in wages that favor unskilled workers over skilled workers, and unskilled workers are concentrated at the bottom of the income distribution.

Three recent studies are also worth mentioning. Ferreira, Fruttero, Leite, and Lucchetti (2011) examine the consequences of food price inflation in Brazil, a large food producer with a predominantly wage-earning agricultural labor force. These authors find large and negative consumption effects, which are also markedly regressive, as expected. However, they also uncover a positive and progressive income effect, particularly in rural areas. Thus, overall the Brazilian middle-income household suffered larger proportional losses than the very poor or the richer households. Jacoby (2013) reaches a similar conclusion in his study of food prices in India. 
Specifically, once the wage gains are accounted for, he finds that rural households across the income spectrum actually benefit from higher agricultural commodity prices. Finally, Nicita, Olarreaga, and Porto (2014) examine the presence of a pro-poor bias in the trade protection of the following six Sub-Saharan African (SSA) countries: Burkina Faso, Cameroon, Côte d'Ivoire, Ethiopia, Gambia, and Madagascar. These authors' model includes consumption effects, agricultural income effects, and labor income effects; they find that trade policies tend to be biased in favor of poor households because protection increases the agricultural prices of goods that are sold by African households, and this effect dominates the impacts on both expenditures and wages.

\section{Spillovers}

Broadly speaking, spillovers are the impacts of a change in market $i$ on the activity in market $j$. There are two types of spillovers: 1) production linkages occur when the expansion of a sector affects upstream activities (backward linkages) or downstream activities (forward linkages); 2) expenditure linkages occur when the increase in income due to the expansion of a sector raises the demand for outputs and thus the derived demand for inputs in other sectors. Given our focus on commodities, we emphasize here spillovers in agriculture. The large body of literature on the topic uncovers two main regularities. First, the linkages are strong in rural areas because households earn a large share of their income from and spend a large share of their total expenditures on goods produced locally. Second, both production and expenditures spillovers are important (Mellor and Johnston 1984; Delgado 1996; Harriss 1987). Evidence on spillovers in agriculture in Latin America can be found in the regional study by De Ferranti et al. (2005). These authors report that while the share of the primary sector in GDP is 12 percent, there are massive spillovers to the rest of the economy. In fact, the multiplier factor from the primary sector to national GDP is 0.22 , so that, for instance, a one percent growth of the rural natural resource sector is associated with an increase of 0.22 percent increase in national GDP (much higher than the 0.12 percent increase to be expected from the sector's share of GDP). At 0.28, the multiplier for the income of the poorest households is even higher.

Note that spillovers can be interpreted as general equilibrium effects, but they are not necessarily the same. If there is some sort of labor immobility in general equilibrium, for instance, then a change in the price of good $i$ may have no effect on the wages paid in sector $j$. In such a scenario there are no spillovers, even in a general equilibrium setting. This distinction is useful to organize our discussion. Of the papers reviewed above, Ravallion (1990) estimates a partial equilibrium model and assumes no spillovers or general equilibrium effects from rice prices to non-agricultural wages. 
An alternative interpretation is that labor markets are segmented. In contrast, Porto (2006) and Nicita (2009) take a general equilibrium approach and assume that a change in a given price $p_{i}$ affects economy-wide wages. This assumes that labor markets are integrated and workers are freely mobile across sectors; an increase in wages in one sector spills over to other sectors.

Porto (2008) describes a variant of the spillover mechanism. Markets can be segmented so that wages can differ across sectors. However, sectors are related via forward and backward linkages, so an expansion of one sector may have implications for other sectors. In such a setting, changes in corn prices in Mexico can affect the corn sector directly, as well as various rural services associated with corn production. For instance, higher corn prices may require more labor in corn planting, weeding, and harvesting (thus causing wages in the corn sector to increase), and may also require farm services (road graveling, farm-gate and fence repair, etc.). Porto finds that allowing for those spillovers can make a big difference in assessing the welfare impacts of higher corn prices. In particular, the average Mexican lowincome household tends to be a net-consumer of corn and consequently is made worse off by an increase in corn prices. However, once spillovers from the corn sector to agricultural wages are allowed to take place, even low-income net-consumers stand to gain from higher corn prices.

As should be clear from this review, the existence or lack of spillovers, and the nature of those spillovers, will be specific to the case under study. It is a priori difficult to make generalizations.

Different types of spillovers arise when other product markets, rather than labor markets, are affected. These spillovers are likely to take place in non-traded goods. As we have shown above, changes in commodity prices affect factor prices, including wages. If the wages earned in non-traded sectors are affected, then the cost of producing these goods will change, and this in turn will affect the equilibrium prices of these goods. As a result, there are additional welfare impacts on the consumption side. Notice that these are first-order impacts. Porto (2006) provides an example of how to estimate these impacts for the case of the countries that are members of the MERCOSUR customs union; he uses time series of prices to recover the elasticity of the price of non-traded goods with respect to the prices of traded products; import tariff cuts by MERCOSUR appear to cause the prices of non-traded goods to decline and households to benefit. It is noteworthy that these spillovers are similar to those highlighted by, for instance, Burstein, Neves, and Rebelo (2003) for the computation of the real exchange rate and the adjustment of prices to stabilization programs.

These types of spillover can be particularly important for some commodity price shocks, especially on energy. Households do spend money directly on energy (electricity, heating), but sizeable effects can be created by spillovers to other good prices. For instance, oil price shocks can affect households via expenditures on transport; 
the direct impacts can be calculated using (exogenous) price changes or shocks and budget shares, as carried out above. To measure the indirect impacts we need to estimate the response of the prices of non-traded goods after commodity price shocks. This can be done with the "price shifting" model proposed by Coady and Newhouse (2006) and Coady et al. (2006). In this methodology, commodity price shocks are fully transmitted to non-traded prices using input-output tables to infer the share of different (commodity) inputs in the production cost structure. The welfare effects at the household level can then be approximated by multiplying the induced price change of non-traded goods and the budget shares from the surveys.

This methodology has been applied extensively to study the distributional effects of fuel subsidies. Much of this work is summarized in Arze del Granado, Coady, and Gillingham (2012), who present cross-country welfare impacts of an increase in the retail price of fuel products by $\$ 0.25$ per liter. These authors find substantial welfare effects of the total (direct and indirect) impact of such a price increase. On average, worldwide, household real income would decline by 5.4 percent; there is regional heterogeneity, as expected. The average welfare impact is the highest in Middle East and North Africa (7.4 percent), Africa (5.4 percent), Asia and Pacific (4.5 percent), and South and Central America (3.3 percent). A key finding of this line of work is that the spillovers - the indirect effects-are very important. On average, the indirect impact accounts for 61 percent of the total welfare effect.

\section{Price Pass-through}

So far, the review has focused on a generic analysis of price changes. Often these price changes, especially if they refer to commodities, are generated by external shocks. It is thus important to review the literature on the pass-through of international prices to the domestic economy, and furthermore to the household. There are various bodies of literature that are relevant here: international economics, international trade, and economic development. While this collection of theories and empirical analyses play different roles in our framework, we can learn from all three of them.

Standard models of international trade and international economics assume competitive markets (and homogeneous goods) and frictionless trade. In this scenario, markets are integrated and the law of one price holds: domestic prices are equal to the international prices converted to the local currency. Any difference between these prices is due to transport and distribution costs as well as to trade policy. In this family of models, a proportional change in the exchange rate, in the international price, or in the tariff is fully transmitted to domestic prices. There is, however, strong evidence against this prediction. The papers reviewed by Rogoff (1996) consistently reject the law of one price for a variety of products and countries. 
The second type of impact arises when distribution costs change. Distribution activities are mostly non-tradable services, which require factors of production such as labor and land. If factor prices react to changes in international prices or exchange rates, then distribution costs will themselves change, and this increase can feed into a larger-than-proportional increase in the domestic price of imported goods. ${ }^{13}$ There is evidence that this mechanism can be relevant in practice. In Argentina, for instance, Burstein, Neves, and Rebelo (2003) show that the distribution margin in both wholesale and retail is around 60 percent. Using calibration methods to compute the impact of a stabilization program (i.e., they study a decline in the exchange rate), the authors find that the increase in the relative prices of non-tradable goods can be 60 percent higher in a model with distribution costs than in a model without such costs. With perfect pass-through, Burstein et al. (2003) assume that the prices of tradable goods decrease in the same proportion as the decrease in the exchange rate, and this affects the prices of non-tradable goods. Without distribution costs, the authors calibrate an increase in the relative price of non-tradable goods of 15.4 percent. With distribution costs, the increase in the price of non-tradables is 25.7 percent.

Another strand of literature is the work on exchange-rate pass-through (ERPT), which is defined as the percentage change in import prices resulting from a 1 percent change in the exchange rate. ERPT models are often associated with imperfect competition in product markets (but they are consistent with perfect competition as well). Goldberg and Knetter (1997) identify two conditions for full pass-through: constant mark-ups, and constant marginal costs. These conditions are unlikely to hold in a given market, and as a result, the literature has found strong evidence of imperfect pass-through. In their review, Goldberg and Knetter (1997) conclude that we should expect a pass-through rate of around 60 percent. Because this paper includes measures of costs in the derivation of the pass-through rate, the results imply that around 40 percent of the change in the exchange rate is actually offset by changes in markups. In a comprehensive analysis of pass-through rates, Campa and Goldberg (2005) find large differences across developed countries. The estimated pass-through rate is 42 percent in the United States, 98 percent in France, 80 percent in Germany, and 46 percent in the United Kingdom.

An interesting paper that attempts to incorporate the estimation of tariff-rate pass-through into the trade and poverty literature is that of Nicita (2009). This author argues that while imperfect price transmission has been established in the literature (as our review suggests), most of the work on the impacts of trade on poverty, and more generally on the distributional impacts of pricing policies, implicitly assume full pass-through. Nicita attempts to fill this gap by estimating tariff-rate pass-through for Mexico; he finds lower pass-through rates for both manufacturing (27 percent) and agriculture (33 percent), and supports these findings by arguing that pass-through is likely to be smaller in a developing country like Mexico due to a lack of domestic transport infrastructure. 
Another important strand of the literature is the work on spatial market integration and the efficiency of arbitrage. In the presence of transport costs, prices across regions differ in the size of the transport costs but should move together due to arbitrage. In practice, three scenarios can be observed: efficiency, characterized by price differentials that can be perfectly accounted for by transport costs; segmented efficiency, characterized by price differentials that are smaller than transport costs (so that markets are competitive but segmented and high transfer costs make trade and arbitrage not profitable); and inefficiency, characterized by price differentials that are larger than transfer costs and thus imply unexploited arbitrage profits (due to market power, for instance). This is relevant for our review because only if markets are efficient will perfect pass-through take place.

There are various procedures to test for spatial market efficiency. ${ }^{14}$ The state-ofthe-art method is the parity-bound model of Sexton, Kling, and Karman (1991), Baulch (1997), and Park et al. (2002), among others. The method relies on maximum likelihood methods to estimate a switching regression model for the three states, namely efficiency, segmented efficiency, and inefficiency. As expected, the evidence is mixed. Baulch (1997) finds that rice markets in the Philippines are spatially efficient and that differences in prices levels are due to transaction costs. Instead, Cirera and Arndt (2006) report inefficiencies in maize markets in Mozambique. Notably, these inefficiencies are somewhat reduced by market liberalization (but not by road rehabilitation), but tend to persist over time. This indicates imperfection in the pass-through rate of commodity shocks.

\section{Household Adjustment in Consumption and Production}

The discussion has followed the traditional first-order approach to assessing the distributional effects of commodity price changes. A major concern with this approach is that it does not allow households to respond to the changes in the economic environment. In fact, even when wage adjustments are incorporated, the standard approach takes the net-consumer/net-producer position of the household as "exogenous." This is just a datum in the analysis that we can assess using survey data, as we did when we described the dependency of households in Latin America and Africa. The net-position of the household is, however, endogenous when households respond.

It is often argued that the first-order approximation can be accurate for small price changes. The "endogeneity" of a household choice in these cases is a secondorder concern in the sense of being unimportant. This is true, and there are numerous examples where the framework works very well. The evaluation of the Doha Development Agenda is one instance, as explored by Hertel and Winters (2006) or Hoekman and Olarreaga (2007). For larger price changes, such as those that can 
be expected from a persistent food-price crisis (or a collapse of global commodity prices), the approximation error grows larger. This section thus explores how large this error can actually become and discusses how the approximation can be improved by measuring household responses in consumption and production.

A consumer will always lose from an increase in prices, but the losses can only be ameliorated by reducing purchases of the more expensive goods. A producer will instead always lose from a price decline. In this case, adjustments can mitigate the losses by shifting resources to more productive activities. Similarly, a farm that hires labor will lose from higher wages, even if labor is substituted with other production factors. Finally, a worker will lose from a reduction in wages, even if he decreases labor supply to enjoy more leisure.

For a farm-household, or more generally in a model where the household participates in multiple markets, adjustments can play a bigger role. In fact, Porto (2008) shows that it is possible for a household to change sides of the market (that is, to become a net-producer after a sufficiently high price increase) so that even an $e x$ ante net-consumer can benefit from a price increase. In what follows, we illustrate various sources of adjustment and discuss attempts to quantify them.

\section{Consumption Responses}

We begin with consumption because research in this area has been prolific. To incorporate consumption responses, research needs to estimate a system of demand elasticities (own- and cross-price elasticities) to identify the pattern of substitution in consumption. The estimation of such a demand system is difficult, however.

There is a long tradition in economics in estimating systems of demand equations. The type of estimation method depends critically on the available data. In the early days when only national account data were available, estimation relied on time series of various consumption aggregates and price indices. The search for a utility-consistent empirical model of demand converged to the almost ideal demand system (AIDS) model of Deaton and Muellbauer (1980), which is now the leading framework for studying demand elasticities.

The mass-production of household surveys in more recent years-a process in which the World Bank has been instrumental — has broadened the options for demand analysis. However, while expenditure surveys provide detailed accounts of what people consume, they collect little information on prices. In some cases, community questionnaires collect price data at the village level, and this variation can be exploited to identify demand elasticities. For those cases in which the surveys collect information on quantities purchased as well as on expenditures, demand elasticities can be recovered from unit values - the ratio of expenditures over quantity. Deaton $(1987,1988,1990)$ developed a model of demand for quantity and 
quality that allows for the extraction of the price signal embedded in the unit values at the level of a market (or cluster of households residing near each other, and thus shopping for consumption goods in the same markets), and these price signals identify the demand elasticities. Because the estimating equations are not necessarily derived from a utility framework (that is, the equations do not form a full-blown AIDS model), the estimated parameters cannot be used to recover the parameters of the utility function. However, they do reveal how household consumption responds to price changes.

Deaton's unit values procedure has been used extensively to examine issues of tax reforms (see, for instance, Deaton (1989b), Deaton and Grimard (1992), and Deaton (1997) for case studies of Thailand, Pakistan, India, and Cote d'Ivoire). ${ }^{15}$ A nice application of Deaton's methods to welfare analysis is the research conducted by Friedman and Levinsohn (2002), who studied consumption responses during the Indonesian financial crisis of 1997. These authors compared the welfare effects resulting from a first-order approximation (that is, without substitution effects) with the ones resulting from a second-order approximation (thus including substitution effects). However, they did not account for wages or, more generally, income responses. Two major findings are worth emphasizing in the context of the discussion about the magnitude of consumption responses to market signals. On the one hand, the losses estimated as first-order approximations for the urban poor were high at roughly 50 percent of the pre-crisis level of per capita expenditures. In rural areas, the losses of the poor were equivalent to nearly 40 percent of their pre-crisis real consumption. On the other hand, allowing for substitution effects in consumption made a big difference. The estimated losses were cut by half for the urban poor and by more than 40 percent overall. These results imply that first-order approximations can be quite large when price shocks are large, such as those observed during the Indonesian crisis (when prices increased by 100 percent or more). In cases of economic crisis, when large price changes may be the norm rather than the exception, the results of Friedman and Levinsohn (2002) warn us about the perils of ignoring second-order terms in welfare analysis. In light of the stylized facts presented above, these adjustments need to be taken into account in the context of the recent surge of commodity prices.

\section{Farm Supply Responses}

We turn now to farm supply responses. As throughout all of our analysis, we are interested in responses at the household level, and especially for the poorest households. ${ }^{16}$ Since these households are typically involved in agriculture, much of our review is concerned with agricultural farm responses.

Conceptually, the issues are those that we discussed within consumption responses. Faced with changed relative prices, the question is whether there is any adjustment in 
production and what factors prevent or facilitate that adjustment. It is perhaps not really surprising to learn that supply responses are somewhat feeble in developing countries. The body of literature is too large for a comprehensive review, but some of most fascinating recent examples include Cadot, Dutoit, and de Melo (2009), who examined vanilla-market reforms in Madagascar, and McMillan, Welch, and Rodrik (2003), who studied cashews in Mozambique.

The evidence on supply responses is not always so bleak, however, as two strands of literature illustrate. First, a common finding in empirical work is that sizeable responses can be expected when price changes are accompanied by appropriate complementary factors such as access to inputs, information, and credit (McKay, Morrissey, and Vaillant 1997), productive assets like animals and tools (Deininger and Olinto 2000), productive capital, education, and land quality (López, Nash, and Stanton 1995; Heltberg and Tarp 2002). Second, there is a growing body of literature showing responses to marketing reforms under successful contract farming arrangements. Two examples illustrate the point: Brambilla and Porto (2011) estimate large adjustments in cotton production after changes in the outgrower contract environment in Zambia, and Maertens and Swinnen (2009) estimate similarly large responses in the vegetable sector in Senegal.

Another way to explore these issues is to look at the performance of subsistence farmers relative to commercial farmers. Subsistence farmers produce for home consumption, whereas commercial farmers earn their income by selling their produce in markets. The evidence indicates that commercial farming is associated with higher consumption and incomes than subsistence farming. Cadot, Dutoit, and Olarreaga (2006) estimate an average loss in income of those in subsistence farming of 43 percent relative to commercial farmers that produce the same crop. Even with much smaller margins, what is puzzling is why subsistence farmers do not transform themselves into commercial farmers by selling their harvest on the market? This question is essentially about supply responses to market signals.

Cadot, Dutoit, and Olarreaga (2010) argue that there are barriers to exit from subsistence agriculture, but the issue highlights explanations of why supply responses to market signals might be sluggish. There are two major barriers here. One is risk: cash crops are riskier than food crops so that part of the difference in return is actually a risk premium (Fafchamps 1992; Rosenzweig and Binswanger 1993). The other barrier is related to missing markets: the differential rate of return is due in part to the shadow price of a good with missing markets such as for labor or food crops (de Janvry, Fafchamps, and Sadoulet 1991). Notice that missing markets can arise due to variable transaction and transportation costs, fixed transaction costs (searching for partners, enforcing contracts with distant buyers, establishing quality), or sunk costs of transacting. One example is Key, de Janvry, and Sadoulet (2000), who illustrate how supply responses are affected by transaction costs. Another interesting example is Cadot, Dutoit, and Olarreaga (2006), who 
show that sunk costs can be particularly large, ranging from 124 to 153 percent of the market value of the average annual farm output in Madagascar.

We end this section with a caveat. Positive and large supply responses to price changes are always an indication that economic incentives work. However, in the context of our analytical framework above, these supply responses comprise secondorder effects. In consequence, they are likely to generate only small welfare impacts because of the opportunity cost of the resources used in the production of different goods. While this argument does not invalidate the search for supply responses in the data, it strongly argues for a careful interpretation of the findings.

\section{Quantifying The Mechanisms: The Case of Mexico}

In this section we use data from Mexico to quantify the different channels uncovered by our review of the literature. The data come from the 2006 Household Income and Expenditure National Survey, ENIGH (Encuesta Nacional de Ingresos y Gastos de los Hogares). The main objective is to illustrate how the mechanisms work. To do this, we work with a (hypothetical) increase of 20 percent in corn prices in rural Mexico. Our results are reported in table 4.

We begin with the first-order consumption and production effects and the netconsumer-net-producer proposition. As discussed in our framework above, the consumption effects are calculated as the product of the budget share spent on corn and the 20 percent price increase. The production effects are the product of the income

Table 4. Welfare Effects of Price Changes, Examples from Mexico

\begin{tabular}{|c|c|c|c|c|c|c|c|c|}
\hline & Q1 & Q2 & Q3 & Q4 & Q5 & All & Net Producers & Net Consumers \\
\hline \multicolumn{9}{|l|}{ First-order Effects } \\
\hline Consumption effects & -3.56 & -2.53 & -1.99 & -1.40 & -0.73 & -1.99 & -0.99 & -2.70 \\
\hline Production effects & 2.25 & 1.86 & 1.65 & 1.49 & 1.12 & 1.60 & 2.78 & 0.77 \\
\hline Net effects & -1.31 & -0.67 & -0.34 & 0.09 & 0.38 & -0.39 & 1.78 & -1.93 \\
\hline \multicolumn{9}{|c|}{ Segmented Labor Markets } \\
\hline Income effects & 5.86 & 4.84 & 4.28 & 3.87 & 2.90 & 4.16 & 7.22 & 1.99 \\
\hline Net effects & 2.30 & 2.31 & 2.29 & 2.47 & 2.17 & 2.17 & 6.23 & -0.71 \\
\hline \multicolumn{9}{|c|}{ Labor Market Spillovers } \\
\hline Income effects & 8.67 & 7.21 & 6.45 & 5.86 & 4.78 & 6.31 & 10.77 & 3.14 \\
\hline Net effects & 5.10 & 4.68 & 4.47 & 4.46 & 4.04 & 4.32 & 9.78 & 0.44 \\
\hline \multicolumn{9}{|l|}{ Second-order Effects } \\
\hline Consumption effects & -3.34 & -2.37 & -1.87 & -1.31 & -0.69 & -1.8 & -0.93 & -2.53 \\
\hline Production effects & 2.48 & 2.05 & 1.81 & 1.64 & 1.23 & 1.76 & 3.05 & 0.84 \\
\hline Net effects & -0.87 & -0.33 & -0.06 & 0.32 & 0.54 & -0.11 & 2.12 & -1.69 \\
\hline
\end{tabular}

Note: Authors' own calculations based on Porto (2008). 
share of corn production and the 20 percent price increase. The net effect is the difference between the production share and the consumption share. For the average Mexican household, an increase in corn prices brings only small welfare losses (equivalent to 0.39 percent of average national income). As expected, there is heterogeneity across quintiles. The largest losses are at the first quintile (-1.31 percent), while quintiles 4 and 5 instead slightly benefit from higher prices. In fact, for these households, the average production effect is larger than the average consumption effect so that poorer households tend to be net consumers of corn, while richer households tend to be net-producers of corn. This illustrates the net-producer/ net-consumer proposition. We can also explore this directly by dividing households into net-producers (those that produce more corn than they consume, independent of the quintile) and net-consumers. The average net producer would enjoy gains equivalent to 1.78 percent of their initial (i.e., pre-price increase) average expenditure. Net-consumers would instead suffer a loss of 1.93 percent.

To incorporate labor market responses, recall that the impacts depend on how wages respond to price changes, and this in turn depends on whether we think that labor markets are integrated or segmented, and upon whether there are spillovers and backward or forward linkages (Ravallion 1990; Porto 2005; Porto 2006). Continuing with the case of corn in Mexico, we provide two examples in table 4. In the second panel, we assume that labor markets are "segmented", and thus we only allow wages in the agricultural sector to respond to corn prices. In this case, we use an agricultural wage elasticity with respect to corn prices of 0.40 (as estimated in Porto 2008). Consequently, an increase in corn prices of 20 percent translates into (roughly) 8 percent higher wages in agriculture. This, in turn, represents a wageincome effect on household welfare that depends on the share of total household income accounted for by agricultural wages. It should be pointed out that we only have information on wage income, and not on labor expenses. Thus, the results from this experiment may be biased upwards. The evidence in Porto (2005) for the Moldovan case suggests that these biases are, however, not very large.

For the average Mexican household, allowing for wage effects induces positive overall welfare effects: higher corn prices would bring welfare increases of 2.17 percent. The average income effects (which includes both the direct production effects of 1.60 and the wage effect) would be 4.16 percent. Since the poor are also agricultural workers, the welfare losses observed above for quintiles 1 to 3 are turned into average welfare gains due to the additional impacts on wages. In fact, the net effect in this (hypothetical) scenario would be roughly similar across the entire income distribution. ${ }^{17}$ The income gains of net-producers jump to 7.22 percent and their net gain becomes 6.23 percent-nearly 3.5 times higher than before. For netconsumers the income gains are more modest at around 1.99 percent, and these gains are not enough to offset the consumption losses. In the end, even with wage responses, net-consumers would be made worse off by the rise in corn prices. 
In another example, in the third panel of table 4, we allow for spillovers from corn prices to the wages of self-employed individuals (in rural areas). The idea is that increases in agricultural prices may increase derived demand for labor in services, odd-jobs and, more generally, in local rural labor markets (not exclusively in agriculture). For the calculations, we use the same wage-price elasticity of 0.40 as before (Porto, 2008). The welfare effects of this expanded wage-income channel thus capture the increase in wages of 8 percent ( 20 percent price increase times the 0.4 wage-price elasticity) filtered through the share of wage income in total household income. We estimate the following welfare impacts: the average national gain would be equivalent to 4.32 percent on initial income; poorer households benefit relatively more than richer households; the income gain of net-producers would be equivalent to 10.22 percent of their initial income, and the net gain would be 9.78 percent; net-consumers would also have an income gain of 3.44 percent and a net gain of 0.44 percent.

As argued above, the net position of the household can be endogenous and it can thus change in response to a price shock. Consider, for example, an increase in the price of corn and let households be able to adjust. If consumption responses are sufficiently strong (because households can substitute easily to other food products) and/or if supply responses are large enough, then a net consumer can in principle become a net producer, and thus benefit from the increase in corn prices. The standard argument against this caveat is that second-order adjustments of the type described here are often small and thus unlikely to change the implications of the first-order calculations. An example is shown in the fourth panel of table 4, where we estimate consumption substitutions and supply responses. To do this, we use an own-price consumption elasticity of corn of -0.61 (as estimated by Porto 2008) and we assume a unitary corn supply elasticity. ${ }^{18}$ To simplify the exposition, we ignore here the wage impacts. As the results show, allowing for consumption and production second-order effects does not, in fact, affect the results. The gains for net-producers are slightly larger and the losses for net-consumers are slightly smaller, but the welfare impacts are not affected much.

\section{Conclusions}

This paper provided an overview of the impacts of price changes on household welfare. We began by exploring commodity dependence in the data and by looking at expenditure and income dependence in the household surveys from Latin American and Africa. Our analysis suggests a strong dependence on commodity prices, a dependence that is biased towards the poor, especially on the consumption side.

The paper then addressed the conceptual issues related to commodity dependence. It did so by laying out a theoretical framework, which described how 
changes in commodity prices affect consumption, production, wages, and household adjustments. Each of these aspects of the analysis of commodity dependence is illustrated with evidence from the existing literature.

Our review tells the story of heterogeneous responses to commodity price changes. Most shocks to commodity prices are international in nature and the passthrough to domestic prices is imperfect (that is, changes in international prices are not translated one-to-one to domestic prices). The pass-through is also heterogeneous across countries and depends on infrastructure, institutions, and market structure (the nature of imperfect competition in domestic markets).

Faced with a price shock, households are affected on both the consumption and income sides. On the consumption side, higher prices cause welfare losses. In Latin America and particularly in Africa, higher food prices can cause large welfare losses, especially for the poor. On the income side, rising commodity prices can bring gains or losses, depending on which goods are produced and also on how wages respond to those price changes. The evidence shows that households tend to earn a significant share of their total income from commodities, so the consumption losses can be ameliorated, sometimes to a large extent. This is most likely to occur when wages and spillovers from commodities to other sectors are taken into account, particularly if wages respond positively to increases in labor demand in primary sectors, and if the spillovers to non-primary sectors are positive (via either production or expenditure linkages). In the end, the overall welfare impacts depend on the net-consumer-net-producer position of the household, after taking into account wage income. Net-consumers will be hurt by price increases, and netproducers will benefit. As expected, these impacts are heterogeneous across countries. Some countries will gain and some others will lose. Also, in a country that gains from higher prices, there will be households that gain and households that lose out. Conversely, there will be winners and losers within countries that lose as an aggregate.

Household adjustments can work as a cushion protecting against price changes. Given a price increase in commodities, consumption responses can ameliorate consumption losses and production responses can boost income gains. Typical adjustments under the separability assumption appear not to be enough to overturn the initial impacts derived from a static view of commodity dependence. Non-separability, which is likely to be a real feature in many developing countries, can work in both directions. Sometimes, market failures can shut down markets completely so that price changes can become irrelevant for many households. While this can work as a protective device, it can also hinder the realization of any efficiency gains and of expanded market opportunities. Sufficiently large price changes in the presence of market failures can generate discontinuities in household responses that can potentially multiply the typically small responses found in the empirical literature - in the real world, the price is not always right. 
We end with some caveats. First, due to space limitations, our review has focused on welfare impacts and we have neglected issues of insurance, coping mechanisms, and social protection policies. Second, the review centered the discussion on oneshot price shocks. In particular, we have not covered the literature on the effects of commodity price volatility. In addition, even in the case of one-shot price shocks, we should note that there might be hysteresis in the effects. In other words, a price shock may have long-term implications, even if the price change reverts at a later date (Baird, Friedman, and Schady 2011). These themes require careful consideration in future assessments of the developmental implications of price signals.

\section{Notes}

Laura Chioda, Louise Cord, Irene Brambilla, and Emily Sinnott provided insightful comments during the early stages of this research project. We are grateful to Emmanuel Jiminez and three anonymous referees for detailed comments on a previous version of this article. We are especially grateful to Cecilia Peluffo and German Bet for their excellent research assistance. All remaining errors are our responsibility.

1. World Bank. Email: dlederman@worldbank.org.

2. Universidad Nacional de La Plata, Calle 6 e 47 y 48, Oficina 521, La Plata 1900, Argentina. Email: guido.porto@depeco.econo.unlp.edu.ar.

3. Data taken from the Global Economic Monitor (GEM) Commodities, found at http:// databank.worldbank.org/data/databases/commodity-price-data. The data presented in the text was accessed on February 7, 2014.

4. World Bank, Press Release No:2011/559/EXT, Washington, DC.

5. See, for example, "Life after the Commodity Boom," The Economist, March 29, 2014.

6. The Latin American surveys are from Socio-Economic Database for Latin America and the Caribbean (CEDLAS and The World Bank). See http://sedlac.econo.unlp.edu.ar/eng/statistics.php. The African surveys used in the analysis are as follows: Burundi (1998), Enquête Prioritaire; Benin (2003), Questionnaire des Indicateurs de Base du Bien-être; Burkina Faso (2003), Enquête Burkinabe sur les Conditions de Vie des Ménages; Côte d'Ivoire (2002), Enquête Niveau de Vie Ménages; Cameroon (2001), Deuxieme Enquete Camerounaise Auprès des Ménages; Ethiopia (2000), Household Income, Consumption and Expenditure Survey; Ghana (1998), Ghana Living Standards Survey; Gambia (1998), Household Economic Survey; Guine-Bissau (2002), Questionário de Indicadores Básicos de Bem-estar; Kenya (1997), Welfare Monitoring Survey III; Madagascar (2005), Enquete Périodique Auprès des Ménages; Mali (2001), L’Enquête Malienne d'Evaluation de la Pauvrete; Malawi (2004), Integrated Household Survey; Nigeria (2004), Nigeria Living Standards Survey; Rwanda (1998), Enquête Integrale sur les Conditions de Vie des Ménages; Senegal (2001), Enquête Senegalaise Auprès des Ménages; Tanzania (2000), Household Budget Survey; Uganda (2005), Uganda National Household Survey; South Africa (2000), Income and Expenditure Survey; Zambia (2003), Living Conditions Monitoring Survey III. See Nicita, Olarrega and Porto (2009) for a detailed description of the surveys.

7. Let $s_{i, t}$ be the commodity income share of household $i$ at time $t$. The cross-section model for $t$ is $s_{i, t}=\mathbf{x}_{i, t}^{\prime} \beta_{t}+\varepsilon_{i, t}$. For $t+1$, the model for household $j$ is $s_{j, t+1}=\mathbf{x}_{j, t+1}^{\prime} \beta_{t+1}+\varepsilon_{j, t+1}$, where we use $j$ instead of $i$ to highlight the fact that these are repeated cross-sections, not panels. We denote $\widehat{\beta}_{t+1}$ the OLS estimates of $\beta_{t+1}$. From the empirical distribution of the residuals, let $\widetilde{\varepsilon}_{i, t+1}$ be the draw attached to household $i$. With these estimates, the prediction for the income commodity shares for household $j$ at time $t$ is $\widetilde{s}_{i, t+1}=\mathbf{x}_{i, t}^{\prime} \widehat{\beta}_{t+1}+\widetilde{\varepsilon}_{i, t+1}$. Note that, since we are taking averages, the residuals vanish (or are very small). Consequently, the lower and upper bounds in Dang, Lanjouw, Luoto, and McKenzie (2011) are very close in our experiment. Below, we report the lower boundary. 
8. An alternative method is to start with the indirect utility function (see Deaton 1997).

9. See Barnum and Squire (1979) and Singh, Squire, and Strauss (1986) for a theoretical discussion of the principle of separability. Benjamin (1992) tests for separability in Indonesia and cannot reject it.

10. To further simplify the exposition, we also assume separability between consumption and leisure in utility.

11. Notice, however, that this analysis does not take into account the fiscal implications of eliminating the tax.

12. Notice that we are referring here to prices of tradable goods. For non-traded goods, the issues are more complex since they are endogenous.

13. Note that this is a type of spillover as those discussed above.

14. See, for instance, Fackler and Goodwin (2002).

15. In short, the difference is that compensated demand elasticities are needed for welfare analysis, and uncompensated elasticities are needed to analyze tax reforms.

16. We do not cover aggregate supply responses in our review.

17. We thank a referee for pointing this out.

18. The formulas for the calculations of the second-order effects are in Porto (2008).

\section{References}

Arze del Granado, F., D. Coady, and R. Gillingham. 2012. "The Unequal Benefits of Fuel Subsidies: A Review of Evidence for Developing Countries." World Development 40 (11): 2234-48.

Baird, S., J. Friedman, and N. Schady. 2011. "Aggregate Income Shocks and Infant Mortality in the Developing World." Review of Economics and Statistics 93 (3): 847-56.

Barnum, H., and L. Squire. 1979. "A model of an Agricultural Household. Theory and Evidence." Ocassional Papers No. 27, World Bank, Washington, DC.

Barrett, C., and P. A. Dorosh. 1996. "Farmers' Welfare and Changing Food Prices: Non-parametric Evidence from Rice in Madagascar." American Journal of Agricultural Economics 78 (3): 656-69.

Baulch, B. 1997. "Transfer Costs, Spatial Arbitrage, and Testing for Food Market Integration." American Journal of Agricultural Economics 79 (2): 477-87.

Benjamin, D. 1992. "Household Composition, Labor Markets, and Labor Demand: Testing for Separation in Agricultural Household Models." Econometrica 60 (2): 287-322.

Benjamin, D., and A. Deaton. 1993. "Household Welfare and the Pricing of Cocoa and Coffee in Côte d'Ivoire: Lessons from the Living Standards Surveys." The World Bank Economic Review 7: 293-318.

Boyce, J., and M. Ravallion. 1991. "A Dynamic Econometric Model of Agricultural Wage Determination in Bangladesh." Oxford Bulletin of Economics and Statistics 53 (4): 361-76.

Brambilla, I., and G. Porto. 2011. "Market Structure, Outgrower Contracts and Farm Output. Evidence from Cotton Reforms in Zambia." Oxford Economic Papers 63 (4): 740-66.

Budd, J. W. 1993. "Changing Food Prices and Rural Welfare: a Nonparametric Examination of the Côte d'Ivoire." Economic Development and Cultural Change 41: 587-603.

Burstein, A., J. Neves, and S. Rebelo. 2003. "Distribution Costs and Real Exchange Rate Dynamics During Exchange-rate-based Stabilizations." Journal of Monetary Economics 50: 1189-214.

Cadot, O., L. Dutoit, and M. Olarreaga. 2006. "The Cost of Moving Out of Subsistence." Mimeo, University of Lausanne, France.

2010. "Barriers to Exit from Subsistence Agriculture." In G. Porto, and B. Hoekman, eds., Trade Adjustment Costs in Developing Countries: Impacts, Determinants and Policy Responses. Washington, DC: CEPR and World Bank. 
Cadot, O., L. Dutoit, and J. de Melo. 2009. “The Elimination of Madagascar's Vanilla Marketing Board, 10 Years On." Journal of African Economics 18 (3): 388-430.

Campa, J. M., and L. S. Goldberg. 2005. "Exchange Rate Pass-through into Import Prices.” The Review of Economics and Statistics 87(4): 679-90.

Cirera, X., and C. Arndt. 2008. "Measuring the Impact of Road Rehabilitation on Spatial Market Efficiency in Maize Markets in Mozambique.” Agricultural Economics 39 (1): 17-28.

Coady, D., M. El-Said, R. Gillingham, K. Kpodar, P. Medas, and D. Newhouse. 2006. "The Magnitude and Distribution of Fuel Subsidies: Evidence from Bolivia, Ghana, Jordan, Mali, and Sri Lanka.” IMF Working Paper No. 06/247. Washington, DC: International Monetary Fund.

Coady, D., and D. Newhouse. 2006. "Ghana: Evaluating the Fiscal and Social Costs of Increases in Domestic Fuel Prices." In A. Coudouel, A. Dani, and S. Paternostro, eds., Poverty and Social Impact Analysis of Reforms, pp. 387-413. Washington, DC: World Bank.

Dang, H., P. Lanjouw, J. Luoto, and D. McKenzie. 2011. "Using Repeated Cross-sections to Explore Movements In and Out of Poverty." Policy Research Working Paper Series 5550, The World Bank, Washington, DC.

De Ferranti, D., G. Perry, D. Lederman, A. Valdes, and W. Foster. 2005. Beyond the City: The Rural Contribution to Development in Latin America and the Caribbean. World Bank, Washington, DC.

De Janvry, A., M. Fafchamps, and E. Sadoulet. 1991. "Peasant Household Behaviour with Missing Markets: Some Paradoxes Explained.” Economic Journal 101: 1400-17.

Deaton, A. 1987. "Estimation of Own- and Cross-Price Elasticities From Household Survey Data." Journal of Econometrics 36: 7-30.

1988. "Quality, Quantity, and Spatial Variation of Price." American Economic Review 78 (3): 418-30.

1989a. "Rice Prices and Income Distribution in Thailand: A Non-Parametric Analysis." Economic Journal 99 (395): 1-37.

. 1989b. "Household Survey Data and Pricing Policies in Developing Countries." The World Bank Economic Review 3: 183-210.

1990. "Price Elasticities from Survey Data." Journal of Econometrics 44: 281-309.

. 1997. The Analysis of Household Surveys. A Microeconometric Approach to Development Policy. Baltimore and London: John Hopkins University Press for the World Bank.

Deaton, A., and J. Muellbauer. 1980. "An Almost Ideal Demand System." American Economic Review 70: $312-36$.

Deaton, A., and F. Grimard. 1992. "Demand Analysis and Tax Reform in Pakistan.” Living Standards Measurement Study. Working Paper No. 85, The World Bank, Washington, DC.

Deininger, K., and P. Olinto. 2000. "Why Liberalization Alone Has Not Improved Agricultural Productivity in Zambia: The Role of Asset Ownership and Working Capital Constraints." World Bank Working Paper No. 2302, Washington, DC.

Delgado, C. 1996. "Agricultural Transformation: The Key to Broad-based Growth and Poverty Alleviation in Africa." In B. Ndulu, and N. van de Walle, eds., Agenda for Africa's Economic Renewal. New Brunswick, NJ: Transaction Publishers.

Dixit, A., and V. Norman. 1980. Theory of International Trade. A Dual, General Equilibrium Approach. Cambridge: Cambridge Economic Handbooks.

Fackler, P. L., and B. K. Goodwin. 2002. "Spatial Price Analysis.” In B. L Gardner, and G. C. Rausser, eds., Handbook of Agricultural Economics. Amsterdam: Elsevier Science.

Fafchamps, M. 1992. "Cash Crop Production, Food Price Volatility, and Rural Market Integration in the Third World." American Journal of Agricultural Economics 74 (1): 90-9. 
Ferreira, F., A. Fruttero, P. Leite, and L. Lucchetti. 2011. "Rising Food Prices and Household Welfare Evidence from Brazil in 2008.” World Bank Policy Working Paper No. 5652, Washington, DC.

Friedman, J., and J. Levinsohn. 2002. "The Distributional Impacts of Indonesia's Financial Crisis on Household Welfare: A 'Rapid Response’ Methodology.” World Bank Economic Review 16: 397-423.

Goldberg, P., and M. Knetter. 1997. "Goods Prices and Exchange Rates: What Have We Learned?" Journal of Economic Literature 35: 1243-72.

Goldberg, P., and N. Pavcnik. 2004. "Trade, Inequality, and Poverty: What Do We Know? Evidence from Recent Trade Liberalization Episodes in Developing Countries." Brookings Trade Forum 2004: $223-69$.

. 2007. "Distributional Effects of Globalization in Developing Countries." Journal of Economic Literature 45 (1): 39-82.

Harrison, A., J. McLaren, and M. McMillan. 2011. "Recent Perspectives on Trade and Inequality." Policy Research Working Paper 5754, The World Bank, Washington, DC.

Harriss, B. 1987. "Regional Growth Linkages from Agriculture." Journal of Development Studies 23 (2): 275-89.

Heltberg, R., and F. Tarp. 2002. "Agriculture Supply Response and Poverty in Mozambique.” Food Policy 27 (2): 103-24.

Hertel, T., and A. L. Winters, eds. 2006. Poverty Impacts of the Doha Development Agenda. Washington, DC: Palgrave-McMillan for the World Bank.

Hoekman, B., and M. Olarreaga, eds. 2007. Global Trade and Poor Nations: Poverty Impacts and Policy Implications of Liberalization. Washington, DC: Brookings Institution Press.

Ivanic, M., and W. Martin. 2008. "Implications of Higher Global Food Prices for Poverty in LowIncome Countries." World Bank Policy Research Working Paper Series No. 4594, Washington, DC.

Jacoby, H. 2013. "Food Prices, Wages, and Welfare in Rural India.” World Bank Policy Research Working Paper No. 6412, Washington, DC.

Key, N., E. Sadoulet, and A. de Janvry. 2000. "Transactions Costs and Agricultural Household Supply Response." American Journal of Agricultural Economics 82: 245-59.

Lederman, D. 2013. "International Trade and Inclusive Growth: A Primer." Indian Growth and Development Review 6 (1): 88-112.

López, R., J. Nash, and J. Stanton. 1995. "Adjustment and Poverty in Mexican Agriculture: How Farmers' Wealth Affects Supply Response.” World Bank Policy Research Working Paper No. 1494, Washington, DC.

Maertens, M., and J. Swinnen. 2009. "Trade, Standards, and Poverty: Evidence from Senegal." World Development 37 (1): 161-78.

McKay, A., O. Morrissey, and C. Vaillant. 1997. "Trade Liberalization and Agricultural Supply Response: Issues and Some Lessons." European Journal of Development Research 9 (2): 129-47.

McMillan, M., K. Welch, and D. Rodrik. 2003. "When Economic Reform Goes Wrong: Cashews in Mozambique." Brookings Trade Forum 97-151.

Mellor, J., and B. Johnston. 1984. "The World Food Equation: Interrelations among Development, Employment and Food Consumption.” Journal of Economic Literature 22 (2): 524-31.

Nicita, A. 2009. "The Price Effect of Trade Liberalization: Measuring the Impacts on Household Welfare." Journal of Development Economics 89 (1): 19-27.

Nicita, A., M. Olarrega, and G. Porto. 2009. "The Poverty Bias of Trade Policy in and Against SubSaharan Africa." Mimeo, University of Geneva, Switzerland.

2014. "Pro-Poor Trade Policy in Sub-Saharan Africa." Journal of International Economics 92 (2): 252-65. 
Park, A., H. Jin, S. Rozelle, and J. Huang. 2002. "Market Emergence and Transition Arbitrage, Transaction Costs and Autarky in China's Grain Markets." American Journal of Agricultural Economics 84 (1): $67-82$.

Porto, G. 2005. "Informal Export Barriers and Poverty." Journal of International Economics 66:447-70. . 2006. "Using Survey Data to Assess the Distributional Effects of Trade Policy." Journal of International Economics 70: 140-60.

2008. "Estimating Household Responses to Trade Reforms. Net Consumers and Net Producers in Rural Mexico.” Policy Research Working Paper No. 3695, World Bank, Washington, DC.

Ravallion, M. 1990. "Rural Welfare Effects of Food Price Changes Under Induced Wage Responses: Theory and Evidence for Bangladesh." Oxford Economic Papers 42: 574-85.

Rogoff, K. 1996. "The Purchasing Power Par- ity Puzzle?” Journal of Economic Literature 34 (2): 647-68.

Rosenzweig, M., and H. Binswanger. 1993. "Wealth, Weather Risk and the Profitability of Agricultural Investment." Economic Journal 103: 56-78.

Sahn, D., and A. Sarris. 1991. "Structural Adjustment and the Welfare of Rural Smallholders: A Comparative Analysis from Sub-Saharan Africa." World Bank Econonomic Review 5: 259-89.

Sexton, R., C. Kling, and H. Carman. 1991. "Market Integration, Efficiency of Arbitrage and Imperfect Competition: Methodology and an Application to US Celery." American Journal of Agricultural Economics 7: 568-80.

Singh, I., L. Squire, and J. Strauss, eds. 1986. Agricultural Household Models: Extensions, Applications and Policy. Baltimore, MD: Johns Hopkins Press for the World Bank.

Winters, A., N. McCulloch, and A. McKay. 2004. "Trade Liberalization and Poverty: The Evidence So Far." Journal of Economic Literature 42: 72-115.

Wodon, Q., C. Tsimpo, P. Backiny-Yetna, G. Joseph, F. Adoho, and H. Coulombe. 2008. "Potential Impact of Higher Food Prices on Poverty: Summary Estimates for a Dozen West and Central African Countries.” World Bank Policy Research Working Paper Series No. 4745, Washington DC. 